\title{
Does Taxable Income under Full Disclosure of Earnings Provide Incrementally Useful Information to Investors?*
}

\author{
Joonhyun KIM ${ }^{1}$
}

Received: June 20, 2020 Revised: July 19, 2020 Accepted: August 10, 2020

\begin{abstract}
This study aims to investigate whether and why the disclosure of full financial information to estimate taxable income (TI) is incrementally useful for investors' decision making at earnings announcements. This paper shows analytically that the information content of TI beyond book income is determined by the relative informativeness of TI exceeding that of book-tax differences (BTDs), and therefore should be affected by the earnings quality of TI relative to BTDs. This study collects data on earnings announcements from Korean listed firms and employs multiple regression tests for earnings persistence, a major indicator of earnings quality, of TI and BTDs and their information content. The empirical test results show that TI is more persistent than BTDs for the entire sample in this study. Further, the investors' reaction to TI is greater than that to BTDs, and the market response to TI controlling for BI is positive. However, the market test results are significantly observed only in the subsample group with full disclosure of financial statements, not in the samples with disclosure of aggregated earnings only. In sum, this study provides new evidence that the TI information obtained from a detailed earnings announcement is useful for investors in addition to book income.
\end{abstract}

Keywords: Earnings Announcement, Taxable Income, Book Tax Difference, Disclosure Quality, Earnings Persistence

JEL Classification Code: H20, G14, M40, M41

\section{Introduction}

It is well known that quarterly earnings announcement plays a key role as new information source for market participants (Basu, Markov, \& Tang, 2013; Dechow, Sloan, \& Zha, 2014). Disclosure of specific financial statements line items contributes to predicting future earnings (Lee, Lee, Choi, \& Kim, 2020), and also enhancing the informativeness of earnings (Livnat \& Zarowin, 1990; Chen, Defond, \& Park,

*Acknowledgements:

(1) This research was funded by 2019 research Grant from Sangmyung University.

(2) An earlier version of this research was presented at the '2019 Spring Conference of Korean Academic Society Accounting' on April 27, 2019.

${ }^{1}$ First Author and Corresponding Author. Assistant Professor, College of Business Administration, Sangmyung University, South Korea [Postal Address: 20 Hongjimun 2-gil, Jongno-gu, Seoul, 03016, South Korea] Email:kimjoonh1@smu.ac.kr

(c) Copyright: The Author(s)

This is an Open Access article distributed under the terms of the Creative Commons Attribution Non-Commercial License (https://creativecommons.org/licenses/by-nc/4.0/) which permits unrestricted non-commercial use, distribution, and reproduction in any medium, provided the original work is properly cited.
2002). The information content of earnings announcement has been dramatically increased from the early 2000 s, and the U.S. firms have been improving their corporate disclosure policy to release more specific financial statements data in earnings announcement (Beaver, McNichols, \& Wang, 2018)

In contrast, the majority portion of quarterly earnings announcements for Korean firms are made in a preliminary form which present aggregated summary information only, not detailed financial statement line items. One of the potentially valuable, but missing detailed information under the preliminary earnings announcement could be taxable income (TI, hereafter) and book-tax differences (BTDs, hereafter), all of which collectively comprise book income (BI, hereafter).

Researchers have noted that tax accounting can provide new information supplementary to that from financial accounting because tax accounting is regulated by law and is less subject to management discretion, and have examined the various qualities of TI and BTDs (e.g., Lev \& Nissim, 2004; Hanlon, 2005; Blaylock, Shevlin, \& Wilson, 2012; $\mathrm{Oh}, \& \mathrm{Ki}, 2019)$. If TI or alternately BTDs has incremental informational value, providing disaggregated information on TI and BTDs in earnings announcement would be beneficial 
to investors. Otherwise, the expanded disclosure would incur nothing but additional cost. Thus, it is important for the purpose of corporate disclosure policy to secure solid empirical evidence on the market effect of disclosure of TI information at earnings announcement.

However, the prior literature is silent about the market effect of tax accounting information at earnings announcement. Instead, most of the relevant studies examine the quality of TI in terms of value relevance, in other words, a long-term association between the tax variables and stock returns (e.g., Hanlon, Laplante, \& Shevlin, 2005; Ayers, Jiang, \& Laplante, 2009; Park, Jung, \& Ko, 2015). However, the value relevance tests capture a long-term association between the earnings information and the economic events that affect firm value, but could not explain whether investors actually utilize TI information in their decision making.

This paper fills the void in the literature by investigating whether and why TI has incremental information content at earnings announcement, utilizing the empirical setting for earnings announcements in Korea. Theoretically, if TI has higher earnings quality than BTDs, the overall market response to the innovation of TI is expected to exceed that of BTDs. As a primary test, this study compares earnings persistence, a critical property of earnings to affect investor's stock valuation (Kormendi \& Lipe, 1987), between TI and BTDs. The test result shows that TI is more persistent than BTDs across the entire sample.

Next, to test for market response to the tax accounting information, the cumulative market-adjusted stock returns (CAR) during the event period $[0,+1]$ around quarterly earnings announcements is regressed on TI and BTDs. Considering that TI is expected to have higher earnings quality than BTDs, especially for earnings persistence, investors are likely to react to the TI information more strongly than the BTDs, provided that the TI information is separately identifiable at earnings announcements. The market test results show that the earnings response coefficient (ERC) for TI change is significantly higher than that for BTDs change, for the firms issuing financial statement line items (the "Full-Disclosure" group). In contrast, firms releasing simply aggregated earnings information in a preliminary form (the "Partial-Disclosure" group) do not have significantly different ERCs between TI and BTDs.

Further, this study reiterates the market test as above using a regression model modified by controlling for BI instead of BTDs. Theoretically, one unit of increase in TI, with BI being constant, leads to the same unit of decrease in BTDs. Therefore, the coefficient on TI in a regression controlling for BI should reflect the impact of TI net of the effect of BTDs, as similarly analyzed by Jennings (1990) and Kim and Kim (2017). Consistently, the empirical findings in this study show that the ERC for TI news after controlling for BI news is significantly positive for the Full-Disclosure group, but insignificant for Partial-Disclosure group.
Taken altogether, the empirical evidence suggests that TI, being more persistent than BTDs, has a greater impact on investors' stock valuation than BTDs, which leads to the incremental information content of TI beyond BI. However, it also suggests that investors cannot utilize TI information effectively unless it is conveyed properly via a detailed corporate disclosure.

As an additional analysis for the association between the quality of tax accounting information and its market effect, I test whether the market reaction to TI and BTDs news for the Full-Disclosure group is affected by BTD consistency, which is an earnings quality factor involved in both book and taxable income. Provided that BTD consistency is associated with consistent tax planning strategy and lower earnings management (Chen, Dhaliwal, \& Trombley, 2012), firms with consistent BTDs are expected to have more informativeness of both TI and BTDs than the other firms. Compatible with this expectation, the test results present that the ERCs for TI and BTDs increase with the BTD consistency, which provides additional evidence that earnings quality of TI and BTDs has considerable impact on the information content of those income items.

This study makes several contributions. First, this study extends the literature on earnings quality of tax-related items including TI and BTDs, by presenting new evidence which highlights the role of TI as a high-quality earnings information. Second, this paper is the first study that verifies the market impact of disclosing TI information. The findings suggest that TI is incrementally useful for investors to revise their expectations of cash flows from a firm in the future. Accordingly, this study supports the expanded disclosure of specific financial information to enable estimating TI as the recent trend in the U.S., and particularly highlights the necessity of improving the disclosure quality of preliminary earnings announcements in Korea.

\section{Literature Review and Hypotheses}

\subsection{Earnings Persistence of TI and BTDs}

Earnings quality is known to be positively associated with future earnings forecast and firm value (Nam, 2019; Dang, Nguyen, \& Tran, 2020). Among the various characteristics of earnings that can affect the earningsreturns relationship, earnings persistence, inter alia, has been discussed as a key element of earnings quality that influences investors' valuation. Kormendi and Lipe (1987) provide a solid theoretical ground demonstrating that the univariate time-series properties of earnings are closely related to the magnitude of stock returns movement in response to earnings innovation. Subsequent studies have presented supporting empirical evidences (e.g., Collins \& Kothari, 1989; Eastern \& Zmijewski, 1989; Nichols \& 
Wahlen, 2004), and furthermore, Dechow and Dichev (2002) suggest that earnings persistence can also serve as a proxy for earnings quality itself.

However, the extant literature regarding tax accounting provides only fragmented evidence on the persistence of taxrelated variables, mostly limited to BTDs. Hanlon (2005) show that earnings of firms with higher BTDs are less persistent than those with lower BTDs. Blaylock, Shevlin, and Wilson (2012) extend Hanlon's (2005) work and find that firms with large positive BTDs show lower earnings persistence.

Although the prior literature provides no direct comparison of the persistence of TI and BTDs, it consistently suggests that BTDs are associated with low earnings persistence. In addition, the temporary portion of BTDs stems from accruals, which are reported to have less persistence into future earnings than cash-based earnings (Sloan, 1996). Jackson (2015) also finds that future pretax income is negatively associated with temporary BTDs. Moreover, permanent BTDs are closely related to government tax policies, including tax exemptions and credits, and thus are likely to vary depending on the external policy environment.

Meanwhile, BTDs can be affected by earnings management and tax manipulation (Desai 2005; Tang \& Firth 2011). Previous research also suggests that large BTDs tend to obfuscate the earnings-returns relation and increase uncertainty among investors (Hanlon, 2005; Comprix, Graham, \& Moore, 2011). Conversely, TI represents the less manageable portion of a firm's core business performance better than BTDs (Lev \& Nissim 2004). Taken together, TI is likely to have higher quality and be more persistent than BTDs, and therefore I suggest the following hypothesis in an alternative form:

\section{H1: TI is more persistent to future earnings than BTDs.}

\subsection{Incremental Market Reaction to TI Surprise}

Considering that the accounting quality of TI is likely to be higher than that of BTDs, particularly in terms of earnings persistence, investors are expected to react to TI news more intensively than BTDs news, all else being equal. Further, previous research suggests that large BTDs tend to obfuscate the earnings-returns relation and increase uncertainty among investors (Hanlon, 2005; Comprix, Graham, \& Moore, 2011). From the perspective of other earnings quality, tax rules are less subject to managerial discretion than GAAP rules (Lev \& Nissim 2004) and therefore TI is expectedly less susceptible to earnings management than BTDs.

Let alone the earnings attributes, disclosure quality is also an important factor in determining the market response to earnings information. Prior research suggests that an enhanced quality of disclosure results in positive market effects such as reducing the cost of capital and increasing market liquidity (Diamond \& Verrecchia, 1991; Botosan, 1997). Concerning earnings announcements, the increase in concurrent disclosures with earnings announcements is positively associated with an increase in the market reaction (Francis, Schipper, \& Vincent, 2002), and the disclosure of disaggregated earnings items has incremental information content beyond aggregated earnings (Swaminathan \& Weintrop 1991; Ertimur, Livnat, \& Martikainen, 2003).

Taken comprehensively, earnings announcements with detailed financial information to estimate taxable income are expected to enable investors to differentiate the earnings attribute of TI from that of BTDs. Thus, shareholders of firms in the Full-Disclosure group with the details for TI estimation are expected to react to TI news more intensively than BTDs news, which suggests the following hypothesis as:

H2a: Investors' response to TI at earnings announcement is greater than that to BTDs.

In a regression model to test for the incremental effect of TI controlling for BI, the explanatory variables are linearly interdependent by construction (i.e., BI = TI + BTDs). In such case, based on the theoretical analysis of Jennings (1990) and Kim and Kim (2017), the incremental information content of TI beyond BI is actually determined by the informativeness of TI relative to that of BTDs. Intuitively, if the market values the BI components, i.e., TI and BTDs, equivalently, simply the aggregated BI number would be sufficient and therefore TI would no longer be additionally informative. Given the above, the incremental information content of TI in addition to $\mathrm{BI}$ is determined by the relative informativeness of $\mathrm{TI}$ over BTDs. As a corollary hypothesis to $\mathrm{H} 2 \mathrm{a}$, TI is predicted to have incremental information content beyond BI, as suggested below:

$\boldsymbol{H} 2 \boldsymbol{b}$ : Investors' response to TI at earnings announcement is positive incrementally beyond that to $B I$.

\section{Research Methods}

\subsection{Measures of Main Variables}

\subsubsection{Cumulative Abnormal Returns}

The dependent variable, $C A R$, is measured by aggregating the daily abnormal stock returns for the 2 days around earnings announcements. The abnormal stock return $(A R)$, which is a firm's daily stock return in excess of the marketmodel return, is calculated by the following equation: 


$$
A R_{j t}=R_{j t}-\left(\hat{\alpha}_{j}+\hat{\beta}_{j} R_{M t}\right)
$$

where $R_{j t}$ and $R_{M t}$ represent the stock returns for firm $j$ and the market index return, respectively, on a daily basis during the event period $[\mathrm{t}=0,1]$. The parameters $\hat{\alpha}_{j}$ and $\hat{\beta}_{j}$ are the estimates obtained from the following regression:

$$
R_{j s}=\alpha_{j}+\beta_{j} R_{M s}+\varepsilon_{j s}
$$

The market model regression in eq. (2) is run for each non-event period, which is defined as the pre-announcement period of $t-60$ to $t-10$ plus the post-announcement period of $t+10$ to $t+60$ surrounding the earnings announcement at date $t=0$, following the work of DeFond, Hung, and Trezevant (2007) and Landsman, Maydew, and Thornock (2012).

\subsubsection{TI and BTDs}

TI is estimated using a firm's financial statements data, based on the rationale that taxable income estimated from financial statements is strongly correlated with actual taxable income (Lisowsky, 2009). In detail, TI is calculated by dividing the current tax expense by the statutory tax rate, where current tax expense equals total tax expense minus deferred tax expense, in line with prior research (Shevlin, 2002; Park, Jung, \& Ko, 2015). Then, I measure BTDs by deducting TI from BI. All the income variables are scaled by lagged market value of equity.

\subsection{Regression Models}

\subsubsection{Test for Persistence of TI and BTDs}

The test for the earnings persistence of TI and BTDs is based on a first-order autoregressive process, named AR(1), which is comparable to time-series models adopted in previous accounting and tax research (Sloan, 1996; Hanlon, 2005). The AR(1) models in this paper are suggested as follows:

$$
\begin{gathered}
T I_{j q}=\beta_{0}+\beta_{1} T I_{j q-1}+\sum \beta_{k} I N D_{k}+\varepsilon_{j q} \\
B T D_{j q}=\beta_{0}+\beta_{1} B T D_{j q-1}+\sum \beta_{k} I N D_{k}+\varepsilon_{j q} \\
B I_{j q}=\beta_{0}+\beta_{1} T I_{j q-1}+\beta_{2} B T D_{j q-1} \sum \beta_{k} I N D_{k}+\varepsilon_{j q}
\end{gathered}
$$

where $T I_{j q}, B T D_{j q}$, and $B I_{j q}$ represent TI, BTDs, and BI for firm $j$ and quarter $q$. All the variables are deflated by the market value of the equity as of the beginning of quarter.
Further to the one-quarter lagged independent variables, the autoregressive process model between the quarters $q-4$ and $q$, is employed as well in consideration of the seasonality of quarterly earnings. Industry dummies $\left(I N D_{k}\right)$ are introduced to control for cross-sectional difference in industry characteristics. The time-series regressions as in eq. (3) and eq. (4) are conducted for each of $T I_{j q}$ and $B T D_{j q}$. As for eq. (5), if TI is more persistent than BTDs as expected, the coefficient $\beta_{1}$ on the lagged variable for TI would be greater than the coefficient $\beta_{2}$ for BTDs.

\subsubsection{Incremental Information Content of TI}

To test for $\mathrm{H} 2 \mathrm{a}$ regarding the comparison of informativeness between TI and BTDs, the following regression model is adopted as:

$$
\begin{aligned}
C A R_{j q}= & \beta_{0}+\beta_{1} \Delta T I_{j q}+\beta_{2} \Delta B T D_{j q} \\
& +\beta_{3} S_{Z I E_{j q}}+\beta_{4} L E V_{j q} \\
& +\beta_{5} \operatorname{REPLAG}_{j q}+\beta_{6} T_{I M E_{j q}} \\
& +\sum \beta_{k} I_{N}+\varepsilon_{j q}
\end{aligned}
$$

The main explanatory variables of interest, $\Delta T I$ and $\triangle B T D$, represent the changes in TI and BTD, respectively, relative to the same quarter of the preceding year (i.e., quarter $q-4)$, based on the assumption of seasonal random walk (Francis, Schipper, \& Vincent, 2002; Dechow, Sloan, \& Zha, 2014). The change variables are scaled by the beginning-ofquarter market value of the equity. The remaining variables are controls for potential factors that affect market response to earnings announcement as identified by prior studies. SIZE is a natural logarithm of the amount of total asset as of the end of the quarter and $L E V$ represents the ratio of debt to total asset at the quarter-end. REPLAG means a reporting lag, which equals the number of days between the fiscal quarter end and the earnings announcement date, to control for variation of market response depending on the earnings announcement timing (Chambers \& Penman 1984; DeFond, Hung, \& Trezevant, 2007). TIME is a time trend variable that represents the number of elapsed fiscal quarters since the first quarter of 1981, and IND represents fixed industry effects.

Earnings announcements on a quarterly basis in Korea take one of the following four types of disclosure (Baik, Kim, \& Lee, 2012): (a) business performance disclosure, (b) notice of material changes in sales or profit, (c) notice of annual shareholders' meeting for approval of financial statements, and (d) periodic filing of business reports. The first two fall under preliminary earnings announcements (i.e., the Partial-Disclosure group) with a simplified form of financial information including sales, profit before tax, and net income. 
The other two types of disclosure provide detailed information based on full financial statements that can be used to estimate TI and BTDs (i.e., the Full-Disclosure group).

Considering that a test for market response to earnings disclosure assumes the respective information is actually released through the disclosure, the market tests in this study adopt the Full-Disclosure group as the main test sample. Whereas, I also conduct the same market test using the Partial-Disclosure group as a control sample. If information similar to TI is revealed by any other source around the earnings announcement, the expected market response to TI may appear even in the Partial-Disclosure group. Therefore, this comparative analysis can contribute to clarifying whether the detailed disclosure of financial statement items is really a new and sole source of information on TI to market participants. In this regard, the coefficient $\beta_{1}$ on $\Delta T I$ in the eq.(6) is expected to be greater than $\beta_{2}$ on $\triangle B T D$ for the Full-Disclosure group but not significantly different for the Partial-Disclosure group where investors cannot obtain the detailed financial information.

Further, I test for $\mathrm{H} 2 \mathrm{~b}$ by regressing $C A R$ for the event period on the unexpected amount of TI controlling for $\triangle B I$ instead of $\triangle B T D$ as in eq.(6), for the Full- and Partialdisclosure groups, respectively. $\triangle B I$ is defined as the change in quarterly BI from the previous quarter $q-4$, deflated by the beginning-of-quarter market value of the equity. The coefficient on $\triangle T I$ controlling for $\triangle B I$ is expected to be positive for the Full-Disclosure group under $\mathrm{H} 2 \mathrm{~b}$, but insignificant for the Partial-Disclosure group.

\subsection{Sample and Data}

The sample consists of quarterly earnings announcements for 48 fiscal quarters from 2004 to 2015 for firms listed in the Korean stock markets. I adopt a quarterly earnings-based approach because earnings announcements for publiclytraded firms in Korea have been made on a quarterly basis, and moreover the interim quarterly announcement is also an important disclosure event that provides timely information preceding the annual earnings announcement.

The accounting and the stock market data is collected from the Korea Listed Companies Association's Total Solution 2000 (TS-2000) and Dataguide Pro of FNGuide. The information on earnings disclosures is obtained from Korea Investor's Network for Disclosure System (KINDS). The initial sample pool consists of non-financial and December-year-end firms with positive book income, to minimize a bias from the significant difference in accounting practices across firms and measurement error in estimating taxable income for loss-making firms. Further, observations with missing values for regression variables are eliminated. In connection with the stock return data, I reject observations with zero stock return for more than half of the event period, or penny stocks with a share price less than KRW 1,000, to mitigate a bias from thinly traded stocks and poor scaling (Landsman, Maydew, \& Thornock, 2012; Ertimur, Livnat, \& Martikainen, 2003). Next, observations with extreme financial numbers for the main explanatory variables are removed to avoid bias from influential outliers, including the firms with fully impaired capital and the samples for which the absolute quarterly change in TI, BI, or BTDs exceeds $50 \%$ of the beginning-of-quarter market value of equity (Ayers, Jiang, \& Laplante, 2009; Mayberry, McGuire, \& Omer, 2015). The finally selected sample comprises 35,052 firmquarters for 1,808 unique firms, while the Full-Disclosure group and the Partial-Disclosure group contains 21,458 and 13,594 firm quarters, respectively. All the continuous variables are winsorized at the upper and lower $1 \%$ of the variable distribution and a firm-clustered standard error is adopted (Petersen, 2009) for all the regressions in this paper.

\section{Empirical Results}

\subsection{Descriptive Statistics and Correlations}

Table 1 presents the descriptive statistics for the main test variables. The mean and median values of $C A R$ for the entire samples are close to zero at 0.001 and -0.002 , respectively, while the distribution is slightly skewed to the right. The levels of BI and TI are positive with average values of 0.039 and 0.028 , respectively, as the sample consists of firms reporting a profit. Rather, the mean and median values for BTD are relatively much closer to zero. The change variables, namely $\Delta \mathrm{BI}, \Delta \mathrm{TI}$, and $\Delta \mathrm{BTD}$, are slightly positive on average and well distributed around the median values of approximately zero. Untabulated, the distribution of the earnings-related variables is similar across the sub-sample groups (i.e., the Full-Disclosure group and the PartialDisclosure group), suggesting that there is no significant discrepancy in earnings attributes between both groups.

Table 2 provides the Pearson and Spearman correlation for the variables relating to the test for information content of earnings announcements for the entire sample. As expected, $C A R$ has a positive correlation with the earnings change variables. SIZE and $L E V$ have insignificant or very weak correlations with CAR. REPLAG is negatively correlated with the return and earnings variables.

\subsection{Regression Results}

\subsubsection{Earnings persistence of TI and BTDs}

In relation to $\mathrm{H} 1$, Table 3 provides the results of the time-series analysis for TI and BTDs for each of the subsample groups. As shown in Panels A of Table 3 for the Full-Disclosure group, the $\operatorname{AR}(1)$ coefficient on $T I_{q-1}$ for 
Table 1: Descriptive Statistics $(N=35,052)$

\begin{tabular}{|l|c|c|c|c|c|c|c|}
\hline Variables & Mean & STD. & $\mathbf{5 \%}$ & $\mathbf{2 5 \%}$ & Median & $\mathbf{7 5 \%}$ & $\mathbf{9 5 \%}$ \\
\hline$C A R$ & 0.001 & 0.052 & -0.079 & -0.027 & -0.002 & 0.025 & 0.091 \\
\hline$B I$ & 0.039 & 0.041 & 0.002 & 0.012 & 0.027 & 0.050 & 0.120 \\
\hline$T I$ & 0.028 & 0.051 & -0.023 & 0.000 & 0.016 & 0.043 & 0.122 \\
\hline$B T D$ & 0.012 & 0.047 & -0.047 & -0.004 & 0.005 & 0.022 & 0.095 \\
\hline$\Delta B I$ & 0.015 & 0.054 & -0.047 & -0.008 & 0.005 & 0.025 & 0.114 \\
\hline$\Delta T I$ & 0.005 & 0.062 & -0.085 & -0.012 & 0.000 & 0.020 & 0.106 \\
\hline$\triangle B T D$ & 0.010 & 0.070 & -0.081 & -0.012 & 0.002 & 0.024 & 0.132 \\
\hline SIZE & 18.988 & 1.393 & 17.174 & 18.022 & 18.710 & 19.690 & 21.840 \\
\hline LEV & 0.388 & 0.188 & 0.098 & 0.232 & 0.387 & 0.534 & 0.697 \\
\hline$R E P L A G$ & 42.056 & 11.084 & 22.000 & 36.000 & 44.000 & 46.000 & 60.000 \\
\hline
\end{tabular}

Table 2: Pearson/Spearman Correlation Matrix $(\mathrm{N}=35,052)$

\begin{tabular}{|c|c|c|c|c|c|c|c|}
\hline Variables & $C A R$ & $\Delta B I$ & $\Delta T I$ & $\triangle B T D$ & SIZE & $L E V$ & REPLAG \\
\hline CAR & & $0.134^{* * * *}$ & $0.057^{\text {t** }}$ & $0.054^{*+* *}$ & $-0.010^{*}$ & $0.023^{*+* x}$ & $-0.028^{* * * *}$ \\
\hline$\Delta B I$ & $0.154^{*+*}$ & & $0.325^{*+* t}$ & $0.491^{\text {t*t* }}$ & $-0.052^{* * * *}$ & $0.136^{*+* t}$ & $-0.047^{* * * *}$ \\
\hline$\Delta T I$ & $0.083^{*+* x}$ & $0.389^{* * * *}$ & & $-0.645^{*+*}$ & -0.006 & $0.034^{* * * x}$ & $-0.022^{* * * *}$ \\
\hline$\triangle B T D$ & $0.049^{* * *+}$ & $0.396^{* * *}$ & $-0.556^{* * *}$ & & $-0.032^{* * *+}$ & $0.076^{*+* x}$ & $-0.016^{* * *+}$ \\
\hline SIZE & $0.006^{*}$ & $-0.061^{4 * t+}$ & 0.010 & $-0.057^{*+* t}$ & & $0.237^{* * * *}$ & $-0.223^{4 * t+}$ \\
\hline$L E V$ & $0.017^{* * * *}$ & $0.114^{* * * *}$ & $0.039^{* * * *}$ & $0.062^{* * * *}$ & $0.245^{* * * *}$ & & $-0.058^{* * * *}$ \\
\hline REPLAG & $-0.036^{* * *}$ & $-0.064^{4 * *+}$ & $-0.044^{\prime * *+}$ & $-0.012^{\prime+*}$ & $-0.123^{* * * *}$ & $-0.040^{4 * t+}$ & \\
\hline
\end{tabular}

Note: The Pearson and the Spearman correlation coefficients are displayed in the upper and the lower diagonals, respectively. ${ }^{* * *},{ }^{* *}$ and * indicates statistical significance at the $1 \%, 5 \%$, and $10 \%$ levels, respectively.

the dependent variable $T I_{q}$ is 0.096 , which is obviously higher than the coefficient estimate of -0.018 on $B T D_{q-1}$ for the dependent variable $B T D_{q-1}$ In the regression model using $B I_{q}$ as a dependent variable to directly compare the persistence of TI and BTDs, the coefficient on $T I_{q-1}$ is 0.169 , which exceeds the coefficient estimate on $B T D_{q-1}^{q-1}$ is 0.109 . The net difference between the coefficients on ${ }^{q-1} I_{q-1}$ and $B T D_{q-1}$ is $0.06(=0.169-0.109)$ and the t-test for the difference is statistically significant at $1 \%$ level. A similar pattern is observed for the Partial-Disclosure group as well. As presented in Panel B of Table 3, the AR(1) coefficient on $T I_{q-1}$ is 0.193 while that on $B T D_{q-1}$ is 0.027 .In the regression adopting $B I_{q}$ as a dependent variable, the net difference between the coefficients on $T I_{q-1}$ and $B T D_{q-1}$ is 0.09 $(=0.281-0.191)$, which is statistically significant at $1 \%$ level. Untabulated, the results of regression analysis replacing the independent variables with the four-quarter lagged $(q-4)$ variables are also qualitatively similar.

Collectively, the results indicate that TI is superior to BTDs in terms of earnings persistence, one of the critical elements of earnings quality to affect investors' valuation. Further, the findings suggest that the sub-sample groups are not fundamentally different from each other in terms of the underlying earnings quality itself for TI relative to BTDs.

\subsubsection{Market response to TI, BTDs, and BI}

Next, Table 4 presents the test results for the incremental information content of TI and the other earnings variables in relation to $\mathrm{H} 2 \mathrm{a}$ and $\mathrm{H} 2 \mathrm{~b}$. For the Full-Disclosure group as shown in Panel A of Table 4, the regression analysis using $\Delta \mathrm{TI}$ and $\triangle \mathrm{BTD}$ as in the Model 1 shows that the coefficient estimate on $\Delta \mathrm{TI}(0.115)$ is greater than that on $\triangle \mathrm{BTD}(0.091)$ and the gap is statistically significant $(\mathrm{t}$-statistics $=4.09)$. This result suggests that investors with the detailed earnings information react more strongly to TI innovation than BTDs news, which is consistent with $\mathrm{H} 2 \mathrm{a}$. In the Model 2 column, the coefficient estimate on $\Delta \mathrm{TI}(0.022)$, controlling for $\Delta \mathrm{BI}$ is significantly positive at the $1 \%$ level. This test result indicates that TI is incrementally useful to investors in addition to BI, being consistent with $\mathrm{H} 2 \mathrm{~b}$. 
Table 3: Comparison of Earnings Persistence between TI and BTDs

\begin{tabular}{|c|c|c|c|c|c|c|}
\hline \multicolumn{7}{|c|}{ Panel A. Full-Disclosure group } \\
\hline \multirow{2}{*}{$\begin{array}{l}\text { Independent } \\
\text { Variables }\end{array}$} & \multicolumn{2}{|c|}{ Dependent Variable $=T I_{q}$} & \multicolumn{2}{|c|}{ Dependent Variable $=B T D_{q}$} & \multicolumn{2}{|c|}{ Dependent Variable $=B I_{q}$} \\
\hline & Coefficient & t-stat. & Coefficient & t-stat. & Coefficient & t-stat. \\
\hline Intercept & 0.033 & $16.18^{* * *}$ & 0.013 & $7.83^{* * *}$ & 0.042 & $21.77^{* * *}$ \\
\hline$T I_{q-1}$ & 0.096 & $9.21^{\star \star *}$ & & & 0.169 & $14.29^{* * *}$ \\
\hline$B T D_{q-1}$ & & & -0.018 & $-2.21^{* *}$ & 0.109 & $11.13^{* * *}$ \\
\hline Fixed effect & \multicolumn{2}{|c|}{ Industry } & \multicolumn{2}{|c|}{ Industry } & \multicolumn{2}{|c|}{ Industry } \\
\hline Adj. $R^{2}$ & \multicolumn{2}{|c|}{0.031} & \multicolumn{2}{|c|}{0.004} & \multicolumn{2}{|c|}{0.069} \\
\hline Observations & \multicolumn{2}{|c|}{21,458} & \multicolumn{2}{|c|}{21,458} & \multicolumn{2}{|c|}{21,458} \\
\hline
\end{tabular}

\begin{tabular}{|c|c|c|c|c|c|c|}
\hline \multicolumn{7}{|c|}{ Panel B. Partial-Disclosure group } \\
\hline \multirow{2}{*}{$\begin{array}{l}\text { Independent } \\
\text { Variables }\end{array}$} & \multicolumn{2}{|c|}{ Dependent Variable $=T I_{q}$} & \multicolumn{2}{|c|}{ Dependent Variable $=B T D_{q}$} & \multicolumn{2}{|c|}{ Dependent Variable $=B I_{q}$} \\
\hline & Coefficient & t-stat. & Coefficient & t-stat. & Coefficient & t-stat. \\
\hline Intercept & 0.028 & $9.58^{* * *}$ & 0.015 & $5.52^{* * *}$ & 0.039 & $14.54^{* * *}$ \\
\hline$T I_{q-1}$ & 0.193 & $10.89^{* * *}$ & & & 0.281 & $17.50^{* * *}$ \\
\hline$B T D_{q-1}$ & & & 0.027 & $1.90^{*}$ & 0.191 & $12.98^{* * *}$ \\
\hline Fixed effect & \multicolumn{2}{|c|}{ Industry } & \multicolumn{2}{|c|}{ Industry } & \multicolumn{2}{|c|}{ Industry } \\
\hline Adj. $R^{2}$ & \multicolumn{2}{|c|}{0.049} & \multicolumn{2}{|c|}{0.008} & \multicolumn{2}{|c|}{0.112} \\
\hline Observations & \multicolumn{2}{|c|}{13,594} & \multicolumn{2}{|c|}{13,594} & \multicolumn{2}{|c|}{13,594} \\
\hline
\end{tabular}

Note: ${ }^{* * *},{ }^{* *}$ and ${ }^{*}$ indicates statistical significance at the $1 \%, 5 \%$, and $10 \%$ levels, respectively.

Table 4: Regression Analysis for Incremental Market Reaction to Taxable Income News

\begin{tabular}{|c|c|c|c|c|}
\hline \multicolumn{5}{|c|}{ Panel A. Full-Disclosure group } \\
\hline \multirow{2}{*}{$\begin{array}{l}\text { Independent } \\
\text { Variables }\end{array}$} & \multicolumn{2}{|c|}{ Model 1: Dependent Variable $=C A R$} & \multicolumn{2}{|c|}{ Model 2: Dependent Variable $=C A R$} \\
\hline & Coefficient & t-stat. & Coefficient & t-stat. \\
\hline Intercept & 0.0027 & 0.38 & 0.0020 & 0.27 \\
\hline$\Delta T I$ & 0.1152 & $12.81^{* * *}$ & 0.0217 & $3.60^{* * *}$ \\
\hline$\triangle B T D$ & 0.0909 & $10.88^{* * *}$ & & \\
\hline$\Delta B I$ & & & 0.1004 & $11.47^{* * *}$ \\
\hline SIZE & -0.0002 & -0.60 & -0.0002 & -0.50 \\
\hline LEV & -0.0004 & -0.17 & -0.0006 & -0.28 \\
\hline REPLAG & 0.0001 & 1.29 & 0.0001 & 1.27 \\
\hline TIME & 0.0000 & -1.06 & 0.0000 & -1.01 \\
\hline Fixed effect & \multicolumn{2}{|c|}{ Industry } & \multicolumn{2}{|c|}{ Industry } \\
\hline Adj. $R^{2}$ & \multicolumn{2}{|c|}{0.012} & \multicolumn{2}{|c|}{0.013} \\
\hline Observations & \multicolumn{2}{|c|}{21,458} & \multicolumn{2}{|c|}{21,458} \\
\hline
\end{tabular}




\begin{tabular}{|c|c|c|c|c|}
\hline \multicolumn{5}{|c|}{ Panel B. Partial-Disclosure group } \\
\hline \multirow{2}{*}{$\begin{array}{l}\text { Independent } \\
\text { Variables }\end{array}$} & \multicolumn{2}{|c|}{ Model 1: Dependent Variable $=C A R$} & \multicolumn{2}{|c|}{ Model 2: Dependent Variable $=C A R$} \\
\hline & Coefficient & t-stat. & Coefficient & t-stat. \\
\hline Intercept & 0.0081 & 1.09 & 0.0063 & 0.84 \\
\hline$\Delta T I$ & 0.1325 & $10.80^{*+* *}$ & -0.0042 & -0.50 \\
\hline$\triangle B T D$ & 0.1329 & $12.51^{\text {t*t* }}$ & & \\
\hline$\Delta B I$ & & & 0.1423 & $13.14^{* *+*}$ \\
\hline SIZE & -0.0009 & $-2.81^{+* * *}$ & -0.0008 & $-2.59^{* * *}$ \\
\hline LEV & 0.0036 & 1.30 & 0.0031 & 1.12 \\
\hline REPLAG & -0.0001 & $-2.84^{+* *}$ & -0.0001 & $-2.83^{* * *}$ \\
\hline TIME & 0.0001 & $2.97^{* * *+}$ & 0.0001 & $3.09^{* * * *}$ \\
\hline Fixed effect & \multicolumn{2}{|c|}{ Industry } & \multicolumn{2}{|c|}{ Industry } \\
\hline Adj. $R^{2}$ & \multicolumn{2}{|c|}{0.022} & \multicolumn{2}{|c|}{0.023} \\
\hline Observations & \multicolumn{2}{|l|}{13,594} & \multicolumn{2}{|l|}{13,594} \\
\hline
\end{tabular}

Note: ${ }^{* * *},{ }^{* *}$ and ${ }^{*}$ indicates statistical significance at the $1 \%, 5 \%$, and $10 \%$ levels, respectively.

On the contrary, the regression result in Panel B of Table 4 shows that the ERC estimates on $\triangle \mathrm{TI}$ and $\triangle \mathrm{BTD}$ for the Partial-Disclosure group are almost the same (coefficient on $\Delta \mathrm{TI}=0.1325$ and coefficient on $\triangle \mathrm{BTD}=$ $0.1329)$, and the difference is not statistically significant (t-statistics $=-0.05)$. As in the Model 2 column, the coefficient estimate on $\triangle T I$ after controlling for $\triangle B I$ for the Partial-Disclosure group is not statistically different from zero. This finding indicates that investors cannot differentiate the implications of TI news from those of BTDs news in the absence of sufficient information on tax accounts and thus TI has no incremental information content for the Partial-Disclosure group.

The other control variables do not have statistically significant coefficients for the Full-Disclosure group, whereas, in the Partial-Disclosure group, SIZE and REPLAG have negative coefficient estimates, indicating that market response decreases with increasing firm size and late earnings announcements for that group. The time trend variable, TIME, has a positive coefficient estimate solely for the Partial-Disclosure group.

In sum, the earnings-return regression results show that investors respond more sensitively to TI information than BTDs, which in turn verifies that the taxable income is incrementally informative over the book income. Furthermore, the investors' response depends critically on the disclosure quality of earnings announcements, and the preliminary earnings announcement without detailed financial information cannot provide investors with a valuable opportunity of utilizing the TI information.

\section{Additional Tests}

\subsection{Sensitivity Analysis}

Various sensitivity tests are performed on model specification changes including (a) a simple random walk model for the earnings-return regressions, (b) three-day event window for calculating $C A R$, (c) different scalar for income variables, (d) alternative measure of taxable income, and (e) elimination of low-growth firms. Untabulated, the main regression findings as above are robust to all the sensitivity tests.

\subsection{Effect of BTD Consistency on the Information Content of TI and BTDs}

The main test results show that the earnings persistence, a key accounting quality, of TI and BTDs affects the market response to the respective earnings information. To further confirm that the earnings quality of TI and BTDs is associated with the ERCs on those variables, I introduce BTD consistency, another important attributes of earnings that could affect the information content of both TI and BTDs.

Previous research suggests that BTD consistency is closely related to the quality of both BI and TI. Ayers, Jiang, and Laplante (2009) find that tax planning and earnings management affect the information content of taxable income relative to book income. Chen, Dhaliwal, and Trombley (2012) provide that consistent tax strategy and less earnings 
management result in consistent relationship between TI and $\mathrm{BI}$, and therefore consistent BTDs, finding the evidence that firms with more consistent BTDs have more informative taxable income and book income.

Under this rationale, firms with consistent BTDs are expected to have high quality of not only BTDs but also TI. Accordingly, their ERCs are expected to be higher than those for firms with less consistent BTDs. To test for the incremental effect of the BTD consistency on the ERCs for the respective earnings components, additional regression analysis is conducted for the Full-Disclosure group as follows:

$$
\begin{aligned}
\text { CAR }_{j q}= & \beta_{0}+\beta_{1} \Delta T I_{j q}+\beta_{2} \Delta B T D_{j q}+\beta_{3} \text { Consistency }_{j q} \\
& +\beta_{4} \Delta T I_{j q} \times \text { Consistency }_{j q}+\beta_{5} \Delta B T D_{j q} \\
& \times \text { Consistency }_{j q}+\beta_{3} \text { SIZE }_{j q}+\beta_{4} L E V_{j q} \\
& +\beta_{5} \text { REPLAG }_{j q}+\beta_{6} T \text { IME }_{j q}+\sum \beta_{k} I N D_{k}+\varepsilon_{j q}
\end{aligned}
$$

where Consistency denotes the BTD consistency which is measured based on the residuals from regressing booktax differences on their major determinants, following Chen, Dhaliwal, and Trombley (2012) and Park, Jung, and Ko (2015). A similar analysis is also conducted replacing $\triangle \mathrm{BTD}$ in eq.(7) with $\Delta \mathrm{BI}$.

The additional test results are summarized in Table 5. Column (1) of Table 5 shows that the coefficients on $\Delta T I \times$
Consistency and $\triangle B T D \times$ Consistency are both positive significantly at the $1 \%$ level. This indicates that consistent BTDs enhance the market reaction to earnings news not only for BTDs but for TI as well. The result is also consistent with the prior research and implies that the investor response is stronger for firms with higher quality TI and BTDs than the other firms. Meanwhile, in a regression using $\triangle B I$ instead of $\triangle B T D$, as shown in column (2) of Table 5 , the coefficient on $\triangle B T I \times$ Consistency is positive but not statistically significant. That is, as the BTD consistency increases the information content of both TI and BTDs, the relative informativeness of TI over BTDs remains unchanged, and therefore the incremental information content of TI beyond $\mathrm{BI}$ is not affected by the BTD consistency.

\section{Conclusions}

This study examines whether taxable income is incrementally useful for investors' decision making around earnings announcements, and investigates the conditions that affect the incremental information content of TI from the perspective of the earnings persistence and the disclosure quality of earnings announcement. The main empirical findings show that TI is more persistent into future income than BTDs for the entire sample, and investors react to

\begin{tabular}{|c|c|c|c|c|}
\hline \multirow{2}{*}{$\begin{array}{l}\text { Independent } \\
\text { Variables }\end{array}$} & \multicolumn{2}{|c|}{ Model 1: Dependent Variable $=C A R$} & \multicolumn{2}{|c|}{ Model 2: Dependent Variable $=C A R$} \\
\hline & Coefficient & t-stat. & Coefficient & t-stat. \\
\hline Intercept & 0.0040 & 0.56 & 0.0033 & 0.47 \\
\hline$\Delta T I$ & 0.0395 & $2.46^{\star *}$ & 0.0109 & 1.03 \\
\hline$\triangle B T D$ & 0.0273 & $1.86^{*}$ & & \\
\hline$\Delta B I$ & & & 0.0344 & $2.14^{* *}$ \\
\hline Consistency & -0.0021 & $-1.67^{*}$ & -0.0021 & $-1.68^{*}$ \\
\hline$\Delta T I$ Consistency & 0.1561 & $5.80^{* * *}$ & 0.0117 & 0.56 \\
\hline$\triangle B T D$ Consistency & 0.1440 & $5.20^{* * *}$ & & \\
\hline$\Delta B /$ Consistency & & & 0.1440 & $4.95^{* * *}$ \\
\hline SIZE & -0.0002 & -0.63 & -0.0002 & -0.55 \\
\hline LEV & -0.0005 & -0.23 & -0.0007 & -0.31 \\
\hline REPLAG & 0.0001 & 1.32 & 0.0001 & 1.28 \\
\hline TIME & 0.0000 & -1.01 & 0.0000 & -0.95 \\
\hline Fixed effect & \multicolumn{2}{|c|}{ Industry } & \multicolumn{2}{|c|}{ Industry } \\
\hline Adj. $R^{2}$ & \multicolumn{2}{|c|}{0.015} & \multicolumn{2}{|c|}{0.015} \\
\hline Observations & \multicolumn{2}{|c|}{21,437} & \multicolumn{2}{|c|}{21,437} \\
\hline
\end{tabular}
TI surprise more strongly than BTDs news for the FullDisclosure group with detailed financial information.

Table 5: Effect of BTD Consistency on Market Reaction to Earnings Surprises

Note: ${ }^{* * *}{ }^{* *}$ and ${ }^{*}$ indicates statistical significance at the $1 \%, 5 \%$, and $10 \%$ levels, respectively. 
The market test results provide that TI is incrementally useful for investors' stock valuation once the information becomes available and the disclosure quality of earnings announcement plays a critical role in enabling the investors to assess the TI information effectively. The findings also have policy implications, highlighting the need for extensive disclosure of tax-related accounts in preliminary earnings announcements to provide a more useful set of information to market participants in a timely manner.

\section{References}

Ayers, B. C., Jiang, J., \& Laplante. S. K. (2009). Taxable Income as a Performance Measure: The Effects of Tax Planning and Earnings Quality. Contemporary Accounting Research, 26(1), $15-54$.

Baik, B., Kim, Y. J., \& Lee, J. (2012). A Study on the Exact Timing of Annual Earnings Announcements in the Korean Market. Korean Accounting Review, 37(4), 253-293. [Printed in Korean].

Basu, S., Duong, T. X., Markov, S., \& Tan, E. J. (2013). How important are earnings announcements as an information source?. European Accounting Review, 22(2), 221-256.

Beaver, W. H., McNichols, M. F., \& Wang, Z. Z. (2018). The information content of earnings announcements: new insights from intertemporal and cross-sectional behavior. Review of Accounting Studies, 23(1), 95-135.

Blaylock, B., Shevlin, T., \& Wilson, R. J. (2012). Tax Avoidance, Large Positive Temporary Book-Tax Differences, and Earnings Persistence. The Accounting Review, 87(1), 91-120.

Botosan, C. A. (1997). Disclosure Level and the Cost of Equity Capital. The Accounting Review, 72(3), 323-349.

Chambers, A. E., \& Penman, S. H. (1984). Timeliness of Reporting and the Stock Price Reaction to Earnings Announcements. Journal of Accounting Research, 22(1), 21-47.

Chen, S., DeFond, M. L., \& Park, C. W. (2002). Voluntary disclosure of balance sheet information in quarterly earnings announcements. Journal of Accounting and Economics, 33(2), 229-251.

Chen, L. H., Dhaliwal, D. S., \& Trombley, M. A. (2012). Consistency of Book-Tax Differences and the Information Content of Earnings. The Journal of the American Taxation Association, 34(2), 93-116.

Collins, D. W., \& Kothari, S. P. (1989). An Analysis of Intertemporal and Cross-Sectional Determinants of Earnings Response Coefficients. Journal of Accounting and Economics, 11(2-3), 143-181.

Comprix, J., Graham, R. C., \& Moore, J. A. (2011). Empirical Evidence on the Impact of Book-Tax Differences on Divergence of Opinion among Investors. The Journal of the American Taxation Association, 33(1), 51-78.
Dang, H. N., Nguyen, T. T. C., \& Tran, D. M. (2020). The Impact of Earnings Quality on Firm Value: The Case of Vietnam. Journal of Asian Finance, Economics, and Business, 7(3), 63-72. https://doi.org/10.13106/jafeb.2020.vol7.no3.63

Dechow, P. M., \& Dichev, I. D. (2002). The Quality of Accruals and Earnings: The Role of Accrual Estimation Errors. The Accounting Review, 77(s-1), 35-59.

Dechow, P. M., Sloan, R. G., \& Zha, J. (2014). Stock Prices and Earnings: A History of Research. Annual Review of Financial Economics, 6(1), 343-363.

DeFond, M., Hung, M., \& Trezevant, R. (2007). Investor Protection and the Information Content of Annual Earnings Announcements: International Evidence. Journal of Accounting and Economics, 43(1), 37-67.

Desai, M. A. (2005). The Degradation of Reported Corporate Profits. The Journal of Economic Perspectives, 19(4), 171-192.

Diamond, D. W., \& Verrecchia. R. E. (1991). Disclosure, Liquidity, and the Cost of Capital. The journal of Finance, 46(4), 1325-1359.

Easton, P. D., \& Zmijewski, M. E. (1989). Cross-sectional Variation in the Stock Market Response to Accounting Earnings Announcements. Journal of Accounting and Economics, 11(2-3), 117-141.

Ertimur, Y., Livnat, J., \& Martikainen, M. (2003). Differential Market Reactions to Revenue and Expense Surprises. Review of Accounting Studies, 8(2), 185-211.

Francis, J., Schipper, K., \& Vincent, L. (2002). Expanded Disclosures and the Increased Usefulness of Earnings Announcements. The Accounting Review, 77(3), 515-546.

Hanlon, M. (2005). The Persistence and Pricing of Earnings, Accruals, and Cash Flows When Firms Have Large Book-Tax Differences. The Accounting Review, 80(1), 137-166.

Hanlon, M., Laplante, S. K., \& Shevlin, T. (2005). Evidence for the Possible Information Loss of Conforming Book Income and Taxable Income. The Journal of Law and Economics, 48(2), 407-442.

Jackson, M. (2015). Book-Tax Differences and Future Earnings Changes. The Journal of the American Taxation Association, 37(2), 49-73.

Jennings, R. (1990). A Note on Interpreting Incremental Information Content. The Accounting Review, 65(4), 925-932.

Kim, J. H., \& Kim, I. H. (2017). What Really Determines the Information Content of Tax Expense and Deferred Tax? Korean Accounting Review, 42(2), 1-44.

Kormendi, R., \& Lipe, R. (1987). Earnings Innovations, Earnings Persistence, and Stock Returns. Journal of Business, 60(3), 323-345.

Landsman, W. R., Maydew, E. L., \& Thornock, J. R. (2012). The Information Content of Annual Earnings Announcements and Mandatory Adoption of IFRS. Journal of Accounting and Economics, 53(1), 34-54. 
Lee, J., Lee, S. J., Choi, S., \& Kim, S. (2020). The Usefulness of Other Comprehensive Income for Predicting Future Earnings. Journal of Asian Finance, Economics, and Business, 7(5), 31-40. https://doi.org/10.13106/jafeb.2020.vol7.no5.031

Lev, B., \& Nissim, D. (2004). Taxable Income, Future Earnings, and Equity Values. The Accounting Review, 79(4), 1039-1074.

Lisowsky, P. (2009). Inferring US Tax Liability from Financial Statement Information. Journal of the American Taxation Association, 31(1), 29-63.

Livnat, J., \& Zarowin, P. (1990). The incremental information content of cash-flow components. Journal of Accounting and Economics, 13(1), 25-46.

Mayberry, M. A., McGuire, S. T., \& Omer, T. C. (2015). Smoothness and the Value Relevance of Taxable Income. The Journal of the American Taxation Association, 37(2), 141-167.

Nam, H.-J. (2019). The effect of earnings quality on financial analysts' dividend forecast accuracy: Evidence from Korea. Journal of Asian Finance, Economics and Business, 6(4), 9198. https://doi.org/10.13106/jafeb.2019.vol6.no4.91

Nichols, D. G., \& Wahlen, J. M. (2004). How Do Earnings Numbers Relate to Stock Returns? A Review of Classic Accounting Research with Updated Evidence. Accounting Horizons, 18(4), 263-286.
Oh, K.-W., \& Ki, E.-S. (2020). Effect of Tax-Related Information on Pre-Tax Income Forecast and Value Relevance. Journal of Asian Finance, Economics and Business, 7(1), 81-90. https:// doi.org/10.13106/jafeb.2020.vol7.no1.81

Park, H. J., Jung, S. Y., \& Ko, J. K. (2015). Book-Tax Conformity, Consistency of Book-Tax Differences and the Information Content of Earnings. Korean Accounting Review, 40(5), 171223. [Printed in Korean].

Petersen, M. A. (2009). Estimating standard errors in finance panel data sets: Comparing approaches. The Review of Financial Studies, 22(1), 435-480.

Shevlin, T. (2002). Commentary: Corporate Tax Shelters and BookTax Differences. Tax Law Review, 55, 427-443.

Sloan, R. G. (1996). Do Stock Prices Fully Reflect Information in Accruals and Cash Flows about Future Earnings? The Accounting review, 71(3), 289-315.

Swaminathan, S., \& Weintrop, J. (1991). The Information Content of Earnings, Revenues, and Expenses. Journal of Accounting Research, 29(2), 418-427.

Tang, T., \& Firth, M. (2011). Can Book-Tax Differences Capture Earnings Management and Tax Management? Empirical Evidence from China. The International Journal of Accounting, 46(2), 175-204. 